九州大学学術情報リポジトリ

Kyushu University Institutional Repository

\title{
Genetic Variation of Hippeastrum Accessions in Vietnam
}

Phuong, Pham Thi Minh

Department of Horticulture, Faculty of Agronomy, HanoiUniversity of Agriculture

Isshiki, Shiro

Department of Applied Biological Sciences, Faculty ofAgriculture, Saga University

Miyajima, Ikuo

Institute of Tropical Agriculture, Kyushu University

https://doi.org/10.5109/1467623

出版情報：九州大学大学院農学研究院紀要. 59 (2)，pp.235-241，2014-08-29. Faculty of Agriculture, Kyushu University

バージョン :

権利関係 : 


\title{
Genetic Variation of Hippeastrum Accessions in Vietnam
}

\section{Pham Thi Minh PHUONG ${ }^{1 *}$, Shiro ISSHIKI ${ }^{2}$ and Ikuo MIYAJIMA ${ }^{3}$}

\author{
Institute of Tropical Agriculture, Kyushu University, \\ Fukuoka 812 - 8581, Japan \\ (Received Apil 4, 2014 and accepted May 12, 2014)
}

\begin{abstract}
The present study was conducted to clarify the distribution and genetic diversity of Hippeastrum accessions cultivated in Vietnam. Twenty-five Hippeastrum accessions collected from 17 provinces in the northern, central, and southern regions of Vietnam were included. Results of floral observation and RAPD analysis indicate that there are four distinct groups of Hippeastrum being grown in Vietnam. These include cam dai (H. puniceum (Lam.) Kuntze syn. H. equestre Herbert), đỏ dại (H. x 'Johnsonii'), đỏ cam dai (H. striatum Lamarck), and the hybrid cultivars. In the RAPD analysis result, 25 primers produced a total of 230 distinct bands, of which 167 were polymorphic (about 72.6\%). The number of polymorphisms per primer ranged from 1 to 13, and one primer did not reveal any polymorphisms. Our phylogeny indicated four separate groups, with dissimilarity values ranging from 0.2 to 0.3 according to the phylogeny based on RAPD results. Some variation was observed between northern, central, and southern $H$. puniceum populations. Extensive variation in flower color, shape, and size was detected among accessions of the hybrid group. While $H$. puniceum is the most widely distributed species from the northern to the southern regions, $H$. x 'Johnsonii' has been observed only in the northern region, but not in the central or southern regions, so the distribution of Hippeastrum within Vietnam might depend on adaptation to environmental conditions. Our results have distinguished the đỏ dai and the cam dai groups, although a single scientific name has been applied to both extant groups in Vietnam. The present study is the first report on the presence and distribution of, and genetic variation among Hippeastrum accessions grown in Vietnam, which will be valuable information for Hippeastrum breeding programs.
\end{abstract}

Key words: genetic variation, Hippeastrum, RAPD analysis, Vietnam

\section{INTRODUCTION}

Hippeastrum is an ornamental flowering bulb that belongs to a genus Hippeastrum which comprised of more than 60 species (Dole and Wilkins, 2004; Banerji et al., 2011) in the Amaryllidaceae family (Traub, 1949; Rees, 1992, Meerow, 1988; Banerji et al., 2011). Because they originated in the subtropical Americas, from eastern Brazil to the southern central Andes of Peru, Argentina, and Bolivia (Traub, 1949; Meerow, 1988; Okubo, 1993), members of this genus are adapted to growth in tropical and subtropical regions. Under natural conditions, Hippeastrum grows in the summer, goes dormant in the winter, and bears beautiful flowers from the end of spring to summer. Hippeastrum is not only well adapted to growth in pot culture, but also for use as a cut flower due to the longevity of its blooms (about 14 d at $20-22^{\circ} \mathrm{C}$ ), which enables them to compete commercially with other popular cut flowers (Read, 2004). Many species in this genus and their hybrids have large, colorful flowers that are prized as Christmas and New Year ornamentals (Silberbush et al., 2003).

In Vietnam, Hippeastrum (commonly referred to as hippeastrum or amaryllis in English, or as loa kèn đỏ, mac chu lan, tú diện, or lan huệ in local languages) has been introduced and grown as an ornamental plant in

\footnotetext{
1 Department of Horticulture, Faculty of Agronomy, Hanoi University of Agriculture, Gialam, Hanoi, Vietnam;

2 Department of Applied Biological Sciences, Faculty of Agriculture, Saga University, Saga 840-8502, Japan;

Institute of Tropical Agriculture, Kyushu University, Fukuoka 812-8581 Japan

* Corresponding author: (E-mail: ptmphuong@hua.edu.vn)
}

home gardens, as a landscape plant, or as a potted plant in many regions. With advancements in the diversity of many characters such as flower color, longevity, and ease of planting and care, Hippeastrum is becoming one of the most valuable commercial flowers. There is a huge diversity of different hybrids of Hippeastrum plants on the market today (Robert et al., 2006); however, there is little documentation of Hippeastrum growing in Vietnam. Recently, there have been many attempts to breed new Hippeastrum varieties, but a lack of important information regarding the distribution of and genetic variation within the genus can increase the time and costs of the breeding process.

To date, several molecular techniques have been developed to complement traditional methods for evaluating the diversity of plant populations. RAPD is such a technique that has been widely applied for genetic analysis of many genera of flowering bulb. Lee et al. (1996) successfully applied RAPD markers to establish a classification system for lilies. In another study, Hamada and Hagimori (1996) used 60 RAPD primers to identify variation among 12 lily varieties while Chakrabarty et al. (2007) traced the relatedness among Hippeastrum varieties in the germplasm collection at the National Botanical Research Institute in Lucknow, India using RAPD analysis. RAPD has also been used for cultivar identification (fingerprinting) (Swoboda and Bhalla, 1997). The efficiency RAPD as a technique for identifying polymorphisms tends to increase with increasing primer length (Yamagishi et al., 2002). Recently, many authors reported that the combination of RAPD analysis and morphological observations can be very effective for studying plant genetic variation (Geraldine et al., 1995; Helena et al., 
1998; Perleb et al., 2000; Pham et al., 2006; Chakrabarty et al., 2007). Thus, in the present study, the RAPD method was used in combination with the observation of floral characteristics to evaluate genetic variation among and between Hippeastrum accessions cultivated in Vietnam.

\section{MATERIALS AND METHODS}

\section{Plant materials}

Bulbs of 25 Hippeastrum accessions were collected from 17 provinces in Vietnam including Caobang, Haiduong, Hagiang, Langson, Sonla, Laichau, Hungyen, Ninhbinh, Hanam, Hanoi, Hatinh, Thuathienhue, Daklak, Hochiminh, Bentre, Soctrang and Lamdong. The sites from which the bulbs were collected are shown in Fig. 1. At the collection sites, the plants were not identified by a species or varietal name. The growers had classified them only according to major flower characteristics such as color red ( $\left.\star^{3}\right)$, red-orange (cam đó), orange (cam), and whether the specimen was a hybrid. The collected bulbs were maintained in the germplasm collection at the Department of Horticulture, Faculty of Agronomy, Hanoi University of Agriculture (HUA), Hanoi, Vietnam. Floral characteristics such as flower shape, size, color, and flower throat color were recorded at each collection site. Subsequent DNA analysis was carried out in the laboratory at the Applied Biological Sciences, Faculty of Agriculture, Saga University, Japan.

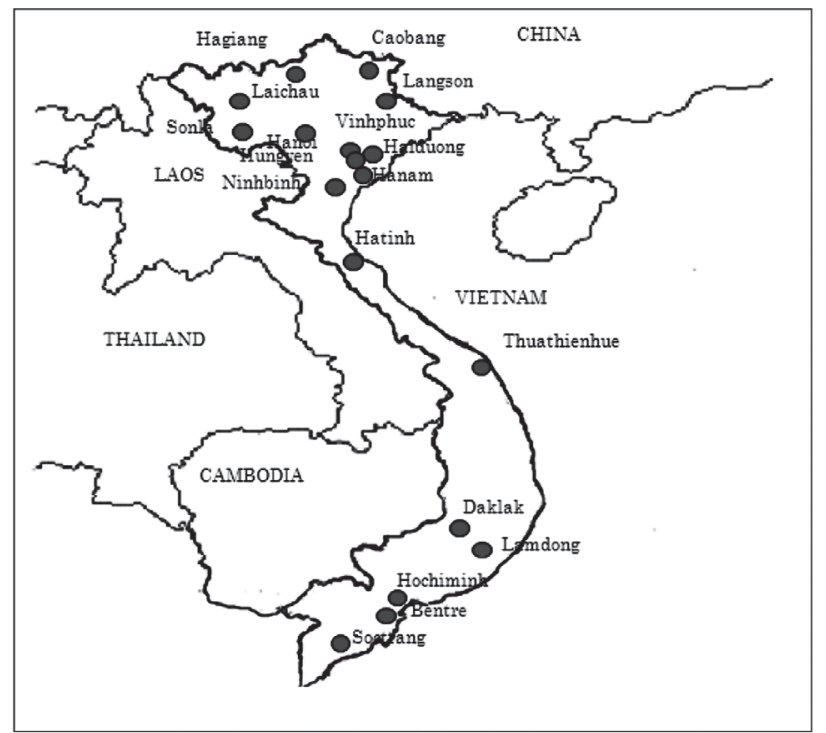

Fig. 1. Collection sites of of Hippeastrum accessions in Vietnam.

\section{RAPD analysis}

Total DNA was extracted from 1-2 g of fresh young leaves of each Hippeastrum accession using the CTAB method, as described by Murray and Thompson (1980), with minor modifications, as described by Yamashita et al. (2000). The PCR was programmed as: initial denaturation for $30 \mathrm{~s}$ at $94^{\circ} \mathrm{C}$, followed by 45 cycles of $30 \mathrm{~s}$ at $94^{\circ} \mathrm{C}, 2 \mathrm{~min}$ at $40^{\circ} \mathrm{C}$, and $3 \mathrm{~min}$ at $72^{\circ} \mathrm{C}$; the final exten- sion for $7 \mathrm{~min}$ at $72^{\circ} \mathrm{C}$. The final reaction mixture was cooled down to $4^{\circ} \mathrm{C}$.

One hundred RAPD primers were tested for the amplification of genomic sequences; 60 random arbitrary 10-bp primers were obtained from Operon Technologies, Inc., (Alameda, California) (designated as primers OPA through $\mathrm{OPF}$ ), and 40 arbitrary 12-bp primers were included in the A primer set from BEX (Tokyo, Japan) (designated as primers A00 through A40). Amplification of RAPD markers from DNA samples from each of six accessions was carried out in triplicate for each PCR run. Only primers that consistently produced clear bands were selected for further experiments.

DNA amplification products were separated by agarose gel electrophoresis. Agarose (1\% w/v) gel with $1 \mathrm{X}$ TAE (40 mM Tris-acetate, 1 mM EDTA (pH 8.5) buffer, and electrophoresis was conducted at $70 \mathrm{~V} / \mathrm{cm}$ for $1.30 \mathrm{~h}$. Gels were stained with ethidium bromide (EtBr), visualized under UV light, and images were captured using a digital camera FAS-III (Toyobo Co. Ltd., Osaka, Japan). All reactions were repeated at least three times and only those bands that were reproducible on all runs were used for further analysis. Molecular Weight Marker II (HindII/EcoRI digested Lambda DNA) was used as a reference to estimate the size of the DNA fragments.

RAPD bands on gels were scored as present $(+)$ or absent ( $(-)$ for each accession studied. To estimate the genetic distance among the strains, the genetic similarity measure $(\mathrm{F})$ for each of the RAPD fragments was calculated using the formula of Nei and Li (1979), F=2 Mxy/ $(\mathrm{Mx}+\mathrm{My})$, where Mxy is the number of shared fragments between the strains ' $x$ ' and ' $y$ '; Mx is the number of fragments scored as strain ' $x$ '; and My is the number of fragments scored as strain ' $y$ '. Distance values were calculated as $1-\mathrm{F}$. The UPGMA clustering method in MEGA version 5 (Tamura et al., 2011) was used to generate a phylogeny.

\section{RESULTS}

\section{Floral observation}

Considerable variation in the floral characters was detected among the accessions we examined (Table 1, Fig. 2). Based on floral characteristics, four different groups of Hippeastrum were distinguished, and were designated cam dại (orange), đỏ dại (scarlet red), đỏ cam dai (red orange), and hybrids, respectively.

Seven cam dai accessions (H37, H53-2, H59, H96, H142, H147, and H56) had small orange trumpet-shaped flowers with a yellowish green throat and a large white star at the base. No variation in the floral characters was observed among cam dai accessions collected from different geographical locations. Some of the floral characteristics of the đo cam dai accessions (H6 and H72) were similar to those of the cam dai accessions, except for the flower and throat color. The flowers of these accessions were red-orange with a yellowish green throat, and a large white star and a red ring at the base. The đó dai accessions (H4, H22, H53-1, H5, and H79) had trumpet-shaped, scarlet red flowers with a yellow- 
Table 1. Collection sites and floral characteristics of the Hippeastrum accessions in Vietnam

\begin{tabular}{|c|c|c|c|c|c|c|}
\hline Accession & $\begin{array}{l}\text { Vietnamese } \\
\text { name }\end{array}$ & $\begin{array}{l}\text { Collection site } \\
\text { (Town, Province) }\end{array}$ & Flower shape & Flower size & Petal color & Throat color \\
\hline $\mathrm{H} 6$ & Cam đỏ & Thuanchau, Sonla & Trumpet & Small & Red orange & Yellowish green, large white star, red ring at the base \\
\hline $\mathrm{H} 72$ & Cam đỏ & Mochau, Sonla & Trumpet & Small & Red orange & Yellowish green, large white star, red ring at the base \\
\hline $\mathrm{H} 4$ & Đỏ dại & Thuanchau, Sonla & Trumpet & Medium & Scarlet red, short white stripe & Yellowish green \\
\hline $\mathrm{H} 22$ & $Đ o ̉$ dại & Duytien, Hanam & Trumpet & Medium & Scarlet red, short white stripe & Yellowish green \\
\hline H53-1 & $Đ o ̉ d a i$ & Gialoc, Haiduong & Trumpet & Medium & Scarlet red, short white stripe & Yellowish green \\
\hline H54 & $Đ o ̉ d a i$ & Caophong, Langson & Trumpet & Medium & Scarlet red, short white stripe & Yellowish green \\
\hline $\mathrm{H} 79$ & $Đ o ̉ ~ d a ̣ i$ & Honglinh, Hatinh & Trumpet & Medium & Scarlet red, short white stripe & Yellowish green \\
\hline H37 & Cam đỏ & Baolac, Caobang & Trumpet & Small & Orange & Yellowish green, large white star \\
\hline H53-2 & Cam đỏ & Gialoc, Haiduong & Trumpet & Small & Orange & Yellowish green, large white star \\
\hline H59 & Cam đỏ & Bacquang, Hagiang & Trumpet & Small & Orange & Yellowish green, large white star \\
\hline H96 & Cam đỏ & Cuchi, Hochiminh & Trumpet & Small & Orange & Yellowish green, large white star \\
\hline H142 & Cam đỏ & Trande, Soctrang & Trumpet & Small & Orange & Yellowish green, large white star \\
\hline $\mathrm{H} 147$ & Cam đỏ & Chauthanh, Bentre & Trumpet & Small & Orange & Yellowish green, large white star \\
\hline H56 & Cam đỏ & Hue, Thuathienhue & Trumpet & Small & Orange & Yellowish green, large white star \\
\hline H104-1 & Cam sọc & Dalat, Lamdong & Triangular & Medium & Orange, small white vein & Yellowish green, red ring at the base \\
\hline $\mathrm{H} 31-2$ & Cam sọc & Tamduong, VinhPhuc & Triangular & Medium & Orange, small white vein & Yellowish green, red ring at the base \\
\hline H52 & Đỏ sọc trăng & Bacson, Langson & Star & Large & Red, large white stripe & Yellowish green, red ring at the base \\
\hline $\mathrm{H} 84$ & Đỏ sọc trắng & Phongtho, Laichau & Star & Large & Red, large white stripe & Yellowish green, red ring at the base \\
\hline $\mathrm{H} 27$ & Trăng & Vangiang, Hungyen & Star & Large & White & Yellowish green \\
\hline $\mathrm{H} 77$ & Trăng sọc tím & Nhoquan, Ninhbinh & Star & Large & White, dark red vein & Yellowish green, red ring at the base \\
\hline H85 & Trăng sọc tím & Mochau, Sonla & Star & Large & White, dark red vein & Yellowish green, red ring at the base \\
\hline $\mathrm{H} 101$ & Hông đào & Dalat, Lamdong & Star & Large & Pale pink and white & Yellowish green, red ring at the base \\
\hline $\mathrm{H} 67$ & Đỏ gáo & Krongbong, Daklak & Star & Medium & Red & Dark red star \\
\hline $\mathrm{H} 28$ & Hông sọc & Dongla, Hanoi & Trumpet & Medium & Pale pink netted vein & Yellowish green \\
\hline H88 & Hông sọc & Cholach, Bentre & Trumpet & Medium & Pale pink netted vein & Yellowish green \\
\hline
\end{tabular}

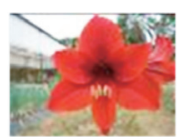

H67

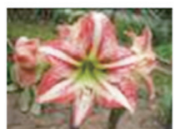

H85

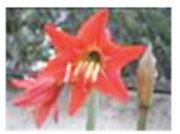

H6

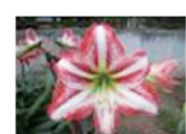

$\mathrm{H} 77$

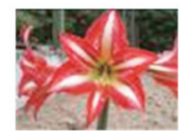
H84

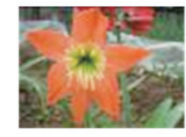

$\mathrm{H} 142$

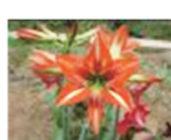

$\mathrm{H} 31 \cdot 2$

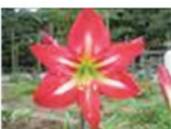

$\mathrm{H} 52$

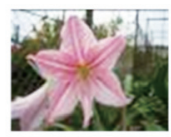

H28

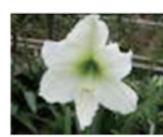

$\mathrm{H} 27$

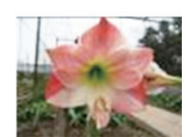

H101

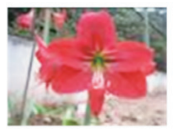

$\mathrm{H} 79$
Fig. 2. Flowers of the Hippeastrum accessions collected in Vietnam.

green throat.

Extensive variation was observed in all the floral characters of the hybrid group. Hybrid flower size was either medium or large. Among hybrid accessions, two (H31-2 and H104) had triangular-shaped flowers, whereas the others had flowers that were star-shaped. Hybrid flower colors varied from dark red (accession H67), to pure white (accession H27), or bi-color (accessions H101, H84, H104, H31-2, H77, and H85). Differences were also observed in the coloration of the flower throats of hybrid accessions. Six of nine accessions had a red ring at the base of the flower throat while accession $\mathrm{H} 67$ had a large dark red star throat. Accessions H28 and H88 were easy to distinguish from other accessions due to their pale pink flowers with netted venation.

\section{RAPD analysis}

From the 100 RAPD primers tested, 25 that consistently produced clear bands were chosen for genotyping the Hippeastrum accessions. RAPD analysis revealed a high degree of genetic diversity among these accessions. The number of bands generated by each primer varied from 3 (for primers A06 and A21) to 14 (for primers OPB-05 and A15), with an average of 9.2 bands per primer. In this study, 24 out of 25 primers produced polymorphic amplification products. A total of 230 distinct bands were produced, of which 167 were polymorphic (about 72.6\%). The number of polymorphisms 
Table 2. Total band number and number of polymorphic bands detected in RAPD analysis of the Hippeastrum accessions in Vietnam

\begin{tabular}{|c|c|c|c|c|c|}
\hline Order & Primer & Sequence & Company & $\begin{array}{c}\text { Total no. of } \\
\text { bands }\end{array}$ & $\begin{array}{l}\text { No. of poly- } \\
\text { morphic bands }\end{array}$ \\
\hline 1 & OPA-01 & 5'-CAGGCCCTTC-3' & Operon & 10 & 9 \\
\hline 2 & OPA-04 & AATCGGGCTG & Operon & 10 & 7 \\
\hline 3 & OPA-17 & GACCGCTTGT & Operon & 12 & 10 \\
\hline 4 & OPA-12 & TCGGCCATAG & Operon & 9 & 6 \\
\hline 5 & OPB-01 & GTTTCGCTCC & Operon & 13 & 11 \\
\hline 6 & OPB-05 & TGCGCCCTTC & Operon & 14 & 11 \\
\hline 7 & OPB-12 & CCTTGACGCA & Operon & 9 & 8 \\
\hline 8 & OPE-01 & CCCAAGGTCC & Operon & 12 & 11 \\
\hline 9 & OPF-03 & ACGGATCCTG & Operon & 9 & 6 \\
\hline 10 & OPF-12 & ACGGTACCAG & Operon & 13 & 9 \\
\hline 11 & OPF-13 & GGCTGCAGAA & Operon & 5 & 3 \\
\hline 12 & OPF-16 & GGAGTACTGG & Operon & 9 & 4 \\
\hline 13 & OPF-18 & TTCCCGGGTT & Operon & 9 & 7 \\
\hline 14 & OPF-19 & CCTCTAGACC & Operon & 9 & 7 \\
\hline 15 & $\mathrm{~A} 00$ & ATCAGCGCACCA & BEX & 4 & 2 \\
\hline 16 & A03 & TGCCTCGCACCA & BEX & 5 & 2 \\
\hline 17 & A06 & ACTGGCCGAGGG & BEX & 3 & 1 \\
\hline 18 & A12 & CTCCTGCTGTTG & BEX & 7 & 4 \\
\hline 19 & $\mathrm{~A} 13$ & CTCAGCGATACG & BEX & 7 & 5 \\
\hline 20 & A15 & ATCGCGGAATAT & BEX & 14 & 13 \\
\hline 21 & A17 & GGTTCGGGAATG & BEX & 7 & 5 \\
\hline 22 & A19 & AGGCGCGAACG & BEX & 7 & 6 \\
\hline 23 & $\mathrm{~A} 21$ & GTGACCGATCCA & BEX & 3 & 2 \\
\hline 24 & A22 & TTCAAGCTACCA & BEX & 8 & 8 \\
\hline \multirow[t]{2}{*}{25} & A26 & GGTGAGGATTCA & BEX & 11 & 10 \\
\hline & Total & & & 230 & 167 \\
\hline
\end{tabular}

detected per primer ranged from 1 (primer A06) to 13 (primer A15), while primer A22 revealed no polymorphism (Table 2). Some primers produced identical RAPD banding patterns for the Hippeastrum accessions with similar physical floral characters, especially flower color. One RAPD marker (about 2000 bp in size) was detected in all the đỏ cam dại and đỏ dạ accessions using primer $\mathrm{OPF}-03$. The primer OPA-04 yielded a RAPD marker (about 830 bp in size) only in the đo cam dai accessions (Fig. 3). The RAPD marker detected using primer OPF-13 (about $400 \mathrm{bp}$ in size) could distinguish the $đ o$ dai accessions from the other accessions. Moreover, one RAPD marker (about 1375 bp in size) was revealed only in the cam dai accessions collected from the southern and central regions, but was not detected in accessions collected from the northern region by using primer $\mathrm{OPF}-16$.

The results from RAPD analysis were used to calculate genetic dissimilarity coefficients in the pair-wise comparisons among the accessions. Genetic distances ranged from a minimum value of 0.008 between accession H142 and accession H147, to a maximum value of

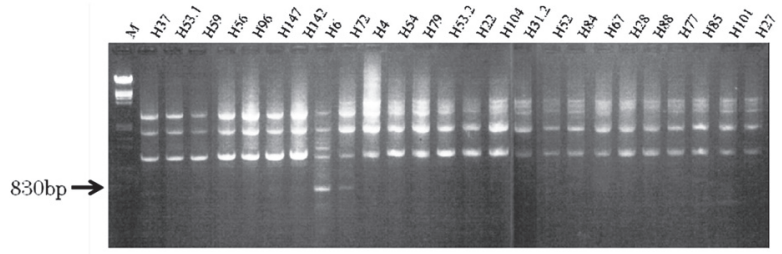

Fig. 3. RAPD profiles of the Hippeastrum accessions in Vietnam generated by primer OPA- 04 .

(M: DNA Size Standard: $\lambda /$ Hind $\mathbb{I I I}-$ EcoRI)

0.357 between accessions H53 and H5 (Fig. 4). The dendrogram developed from the genetic dissimilarity values revealed by RAPD analysis is shown in Fig. 5. At genetic dissimilarity values greater than 0.3 , two distinct clusters of accessions were observed. The first cluster included 16 Hippeastrum accessions of the đó dai and the hybrid groups, while the second cluster included nine accessions from the cam dai and the đỏ cam dai groups. Within the first cluster, two subgroups were clearly identified with a dissimilarity value greater than 0.2 . Accessions with similar flower color, shape, and size were always in 


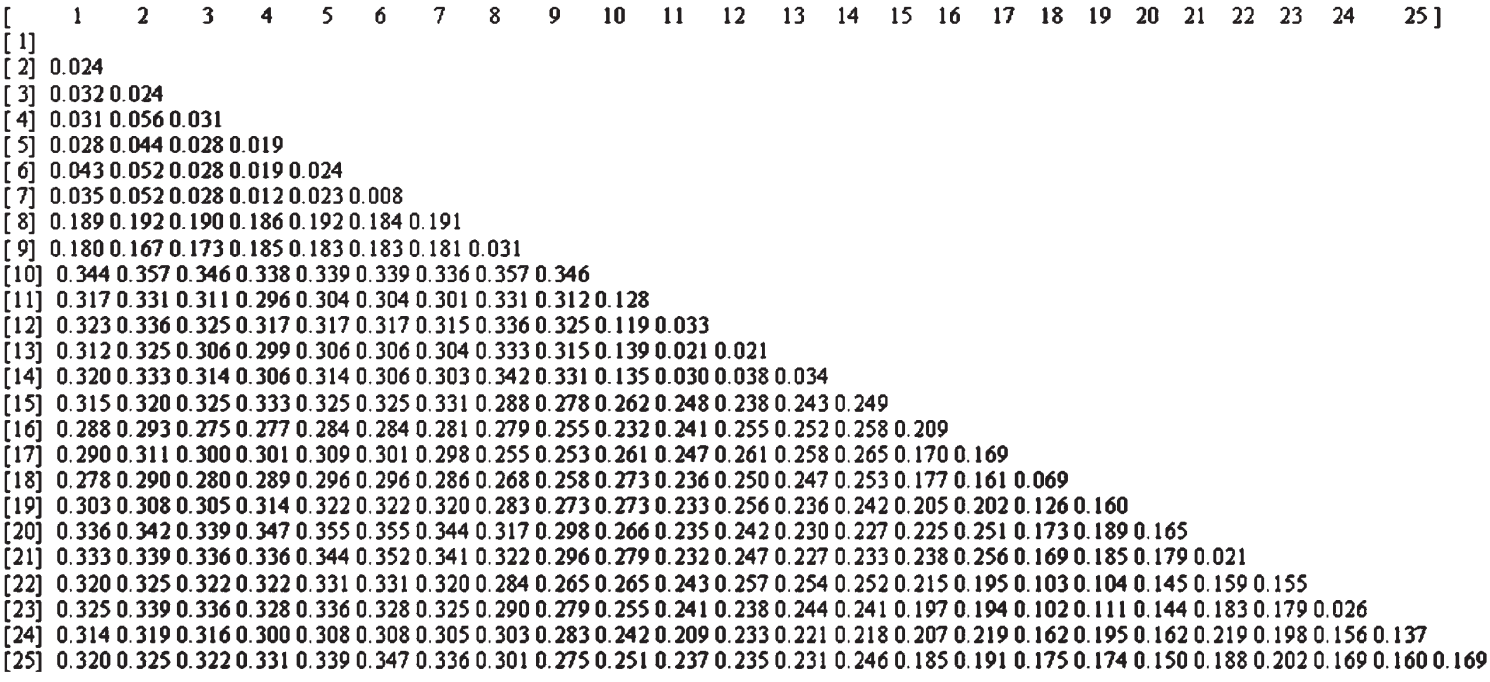

Fig. 4. Dissimilarity values based on RAPD analysis among the Hippeastrum accessions in Vietnam.

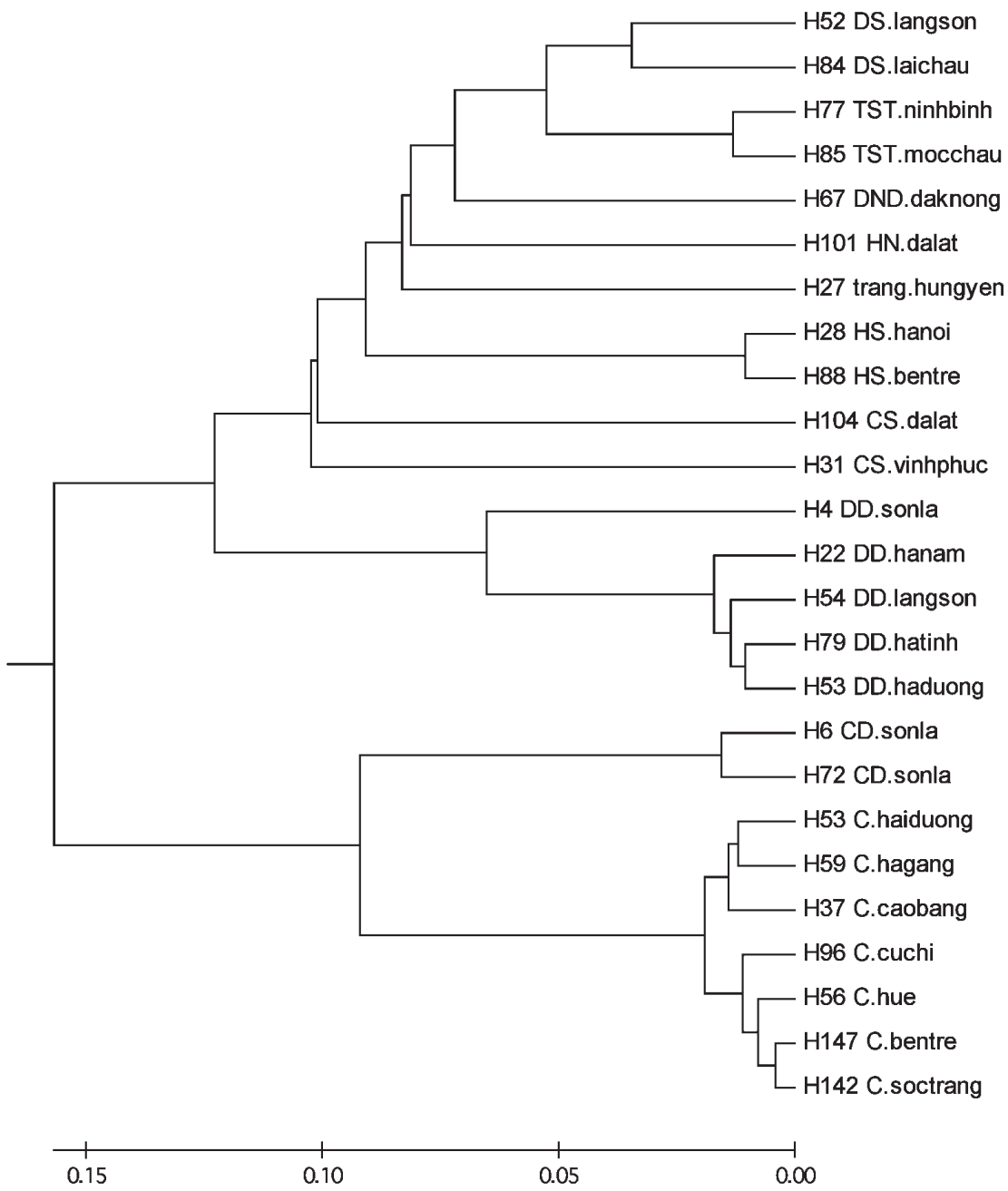

Fig. 5. Dendrogram of the Hippeastrum accessions in Vietnam developed from RAPD data. 
close proximity in the dendrogram (e.g., accessions H52 and H84, or H28 and H88, or H77 and H85). These accessions clustered into three small branches of the dendrogram, which indicates their relatively close relationship. In a second cluster, two different subgroups could be distinguished. One included the cam dai accessions, and the other included two đỏ cam dai accessions. Although all of the cam dai accessions were relatively close, they were separated into two small branches on the dendrogram. The accessions H53, H59, and H37 collected from the northern region (Haiduong, Hagiang, and Caobang provinces, respectively) were grouped into one branch. However, the accessions H96, H56, H147, and H142 collected from the central and southern regions (Thuathienhue, Hochiminh, Bentre, and Soctrang provinces, respectively) were clustered on another short branch, indicating their close relationship.

\section{DISCUSSION}

Based on floral observation and results of the RAPD analysis in the present study, four different groups of Hippeastrum cultivated in Vietnam were revealed. Those groups could identified as cam dai, or Hippeastrum puniceum (Lamk.) Kuntze (syn. Hippeastrum equestre Herb.); đỏ dai, or Hippeastrum x 'Johnsonii'; đỏ cam dai, or Hippeastrum striatum Lamarck ; and the lai or hybrid group. These findings are not in agreement with those of other authors as to the number of extant Hippeastrum species and cultivars currently in Vietnam. Previous reports had indicated only two Hippeastrum species cultivated in Vietnam as $H$. reticulatum Herb. (a subspecies $H$. reticulatum Herb. var. striatifolia Herb.), and H. puniceum (Lamk.) Kuntze (syn. H. equestre Herb.) (Ho, 1999; Do et al., 2007).

There is also an apparent contradiction in classification based on the flower color of $H$. puniceum (syn. $H$. equestre Herb.) in Vietnam. According to Do et al. (2007), the flowers of $H$. puniceum are red or orange; however, Ho (1999) reported flowers of this species to be red. In our study, accessions that were identified as H. puniceum had orange flowers with yellowish green throats and a large white star at the base, the same as described for H. puniceum by Traub (1949), Okubo (1993), and Read (2004).

Among these Hippeastrum groups, H. puniceum is the most widely distributed in Vietnam. It is found in home gardens from the northern region to the southern region. It is also important to note that Vietnam has two distinct climate regions: a northern region that is characterized by four distinct seasons including a cold winter, and the southern and central regions that are characterized by two distinct seasons, hot and rainy or hot and dry. H. puniceum flowers at the beginning of the rainy season in the southern and central regions, but flowers at end of spring in the northern region, when the weather is still cold and dry. It seems that flower initiation in $H$. puniceum in Vietnam does not appear to depend on vernalization, but on exposure to dry conditions. Therefore, the study on the flower initiation of $H$. puniceum is essential. Moreover, RAPD analysis identified some genetic variation between the $H$. puniceum populations from the northern region compared to those from the southern and central regions. All of the accessions collected from the southern and central regions (H96, H56, H147, and H142) could be phylogenetically distinguished from those collected in the northern region (H53, H59, and H37) with this RAPD data. Thus, the variation observed between $H$. puniceum populations of the northern region and those of the southern and central regions could have resulted from the adaptation of each population to these different climactic conditions.

To date, the name H. equestre (syn. H. puniceum) has been applied to accessions belonging to both the $đ o$ dai and the cam dai groups in Vietnam. However, our study indicates that accessions of the $đ o ̉$ dai and cam dai groups are likely separate, as depicted in the dendrogram developed from analysis of this RAPD data. There is significant genetic variation (genetic distance value $>0.3$ ) between these two groups. Also, based on observation of the floral characteristics of each accession, the đo dai accessions could be redesignated as $H$. $\mathrm{x}$ 'Johnsonii', which is known to be a hybrid of $H$. reginae x H. vittatum (Traub, 1949; Meerow et al., 1990, and Read, 2004). H. x 'Johnsonii' is cultivated in the northern region for its scarlet red flowers, but is not grown in the southern or central regions. Its flowering season is at the end of spring, although it does flower rarely in summer or winter.

Plant classifications based on morphological characteristics can sometimes present problems for taxonomists, but RAPD analyses can help to resolve such ambiguities (Swoboda and Bhalla, 1997). It is not uncommon for incorrect scientific names to persist locally, as in the case of the classification of Allium species occurring in Vietnam. Pham et al. (2006) had previously distinguished the wakegi onion (Allium wakegi Araki) from the shallot (Allium cepa, Agregatum group) using cytological, morphological, and RAPD analysis, although both had previously been classified as part of the A. cepa Agregatum group. Similarly, the present study is the first report distinguishing $H$. puniceum and $H$. x 'Johnsonii' in Vietnam.

H. striatum has not been officially reported to occur in Vietnam, but has only been informally observed in some northern provinces in Vietnam, including Hanoi, Thanhhoa, and Sonla provinces (personal observation). Although the flower size and shape of $H$. striatum are similar to those of $H$. puniceum, the genetic diversity between these two species is considerable (approximately 0.2). Due to small sample numbers, genetic variation among the $H$. striatum accessions has not yet been determined. Further studies of the morphological, cytological, and physiological characteristics of $H$. striatum are necessary to confirm whether those accessions are distinct at the species or lower level.

The demand for the new Hippeastrum cultivars is increasing in Vietnam and worldwide. Consequently, a number of new cultivars have been imported into the country for cultivation. The present study has revealed 
significant genetic variation among Hippeastrum accessions of the hybrid group. The available diversity of flower color, shape, and size of these new cultivars will be useful for Hippeastrum breeding in Vietnam. Among the hybrid accessions, hông soc, or $H$. reticulatum Herb. var. striatifolia Herb., is particularly easy to identify due to its pale pink flowers with netted venation and a white stripe on the leaves (visual observation). This accession blooms in September, while others flower from March to May. According to Meerow (1988) the flower emergence of these groups may be affected by a photoperiodic response more than by low temperatures. In particular, the variety hông sọc could become an important genetic resource for breeding late-blooming Hippeastrum varieties.

In addition to providing valuable information on the relationships among and distribution of Hippeastrum species and varieties in Vietnam, our report also agrees with that of Chakrabarty et al. (2007) in that the RAPD method is useful for identifying new and existing hybrids, and for determining the relatedness of Hippeastrum accessions. The useful RAPD primers and the RAPD markers developed in the present study could be used in further research to analyse the relationships between Hippeastrum species, hybrids, and varieties not only in Vietnam, but also in other countries.

\section{ACKNOWLEDGMENTS}

This research was financed by the National Foundation for Science and Technology Development (NAFOSTED), the Ministry of Science and Technology of Vietnam (Reference code: 106.11-2010.46), which we would like to thank for supporting this research. We would like to thank Dr. Alan Meerow of the University of Florida-IFAS for his invaluable advice regarding Hippeastrum identification.

\section{REFERENCES}

Banerji, B. K., A. Batra, M. Saxena and A. K. Dwivedi 2011 Morphological, anatomical and palynological characterizations of Hippeastrum cultivars. Herbertia, 65: 297-308

Chakrabarty, D., V. N. Gupta and S. K. Datta 2007 Varietal identification and assessment of genetic relationships in Hippeastrum using RAPD markers. Plant Biotechnol. Rep., 1: $211-217$

Do, N. T. 2007 Bộ hoa loa kèn - Liliales In "Thực vật chí Việt Nam (Flora of Vietnam)", Vol. 8, ed. by Do, N. T Science and Techniques Publishing House, Hanoi, Vietnam pp: 73-77 (in Vietnamese)

Dole, J. M. and H. F. Wilkins 2004 Hippeastrum. In "Floriculture: Principles and Species", Pearson Education, Inc., Upper Saddle River, New Jersey (United States) pp. 588-592.

Geraldine, A. A., J. A. Antons, A. C. Worley, T. A. Stuttill and R. J. Hebda 1995 Morphological and genetic variation in disjunct populations of the avalanche lily Erythronium montanum. Can. J. Bot., 74: 403-412

Hamada, K. and M. Hagimori 1996 RAPD-based method for cultivar-identification of calla lily (Zantedeschia spp.). Sci. Hortic., 65 (2-3): 215-218

Hellena, A. P., K. Lundquist and H. Nybom 1998 RAPD analysis of genetic variation within and among population of Turk's-cap lily (Lilium martagon L.). Hereditas, 128: 213- 220

Ho, P. H. 1999 Cây cỏ Việt Nam (An Illustrated Flora of Vietnam) Young Press, Hanoi (Vietnam) pp. 497- 498 (in Vietnamese)

Lee, J. S., P. O. Lee, Y. P. Lim, E. M. Shin and S. Y. Park 1996 Classification of lilies using random amplified polymorphic DNA (RAPD) analysis. Acta Hort., 414: 137-144

Meerow, A. W. 1988 New trends in amaryllis (Hippeastrum) breeding. Proc. Fla. State Hort. Soc., 101: 285-287

Meerow A. W., M. E. Kane and T. K. Broschat 1990 Breeding of new Hippeastrum cultivars using diploid species I. The F-1 evaluation. Proc. Fla. State Hort. Soc., 103: 168-170

Murray, M. G. and W. F. Thompson 1980 Rapid isolation of high molecular weight DNA. Nucleic Acids Res., 8: 4321-4325

Nei, M. and W. Li 1979 Mathematical model for studying genetic variation in terms of restriction endonucleases. Proc. Natl. Acad. Sci. USA, 76: 5269-5273

Okubo, H. 1993 Hippeastrum (Amaryllis). In "The Physiology of Flower Bulbs", ed. by A. D. Hertogh and M. L. Nard. Elsevier, Amsterdam (The Netherlands) pp. 321-324

Perleb, P. F., V. Terzi, N. Pecchioni, T. Berio, A. Giovannini and A. Allavena 2000 Genetic diversity in cultivated Osteospermum as revealed by random amplified polymorphic DNA analysis. Plant Breeding, 119: 351-355

Pham, T. M. P., S. Isshiki and Y. Tashiro 2006 Genetic variation of shallot (Allium cepa L. Aggregatum Group) in Vietnam. J. Japan. Soc. Hort. Sci., $\mathbf{7 5}(3)$ : 236-242

Rees, A. 1992 Ornamental bulbs, corms and tubers. In "Crop Production Science Horticulture 1", No. 1, CAB International, Wallingford (UK) pp. 36

Robert B., M. Jordheim, B. Kiremire, J. Namukobe and Ø. M. Andersen 2006 Anthocyanins from flowers of Hippeastrum cultivars. Sci. Hortic., 109: 262-266

Read, V. M. 2004 Hippeastrum: The gardener's amaryllis. Royal Horticultural Society Plant Collector Guide. Timber Press, Cambridge (UK)

Silberbush, M., J. E. Ephrath, C. Alekperov and J. B. Asher 2003 Nitrogen and potassium fertilization interactions with carbon dioxide enrichment in Hippeastrum bulb growth. Sci. Hortic., 98: $85-90$

Swoboda, I. and P. L. Bhalla 1997 RAPD analysis of genetic variation in the Australian fan flower, Scaevola. Genome, 40: 600606

Tamura, K., D. Peterson, N. Peterson, G. Stecher, M. Nei and S. Kumar 2011 MEGA5: Molecular Evolutionary Genetics Analysis using Maximum Likelihood, Evolutionary Distance, and Maximum Parsimony Methods. Molecular Biology and Evolution, 28: 2731-2739

Traub, H. P. and H. N. Moldenke 1949 Amaryllidaceae: Tribe Amaryllis. Amer. Plant Life Soc., La Jolla (United States) 194: $133-134$

Yamagishi, M., H. Abe, M. Nakano and A. Nakatsuka 2002 PCRbased molecular markers in Asiatic hybrid lily. Sci. Hortic., 96(1-4): 225-234

Yamashita, K., R. Noda and Y. Tashiro 2000 Use of mitochondrial DNA polymorphism to distinguish cytoplasms of cultivated and wild species in section Cepa of Allium. J. Japan. Soc. Hort. Sci., 69: 396-402 